\title{
Conceptual Notes on the Internal Business Environment Analysis and the Stra.Tech.Man Synthesis
}

\author{
Charis Vlados (Corresponding author) \\ Department of Economics, Democritus University of Thrace \\ PO Box 69100, Komotini, Greece \\ Tel: +302531039824Ｅ-mail: vlad.coop@gmail.com
}

Received: Oct. 27, 2019 Accepted: Nov. 20, 2019 Published: Dec. 5, 2019

doi:10.5296/bmh.v7i2.15993 URL: http://dx.doi.org/10.5296/bmh.v7i2.15993

\begin{abstract}
This paper examines the theoretical contributions on the firm's resources and the articulation of competitive advantages, the firm's value chain analysis, and the comprehension of the "intangible nature" of the firm in the discipline of the internal organizational environment analysis. The aim is to synthesize these approaches from a critical perspective and attempt to enrich them conceptually based on the "biological perception" and "physiology" of the firm. To this end, the Stra.Tech.Man approach, which exploits interpretatively a synthesis of the evolutionary spheres of strategy, technology, and management for the "living" socioeconomic organization, seems capable of unifying the previous approaches analytically and enrich them.
\end{abstract}

Keywords: Internal business environment, Evolutionary internal business environment analysis, Stra.Tech.Man approach, Firm’s physiology, Firm's biological approach 


\section{Introduction}

The internal business environment analysis constitutes a significant contribution to modern strategic planning. The exploration of the inner structural socioeconomic elements that comprise the internal environment of the firm is one of the two critical pillars of articulating an integrated business strategy -together with the external business environment. Based on a simultaneous examination of these two analytical dimensions (external and internal environment), SWOT analysis can be further consolidated, which is the source of the subsequent strategic planning of the firm and which results in the overall strategic plan (Vlados, 2019b; Vlados \& Chatzinikolaou, 2019c).

However, very often, the internal business environment analysis seems to be also governed by some interpretive limitations and analytical misunderstandings. Quite often within the firm, the analysis of the internal environment and the dimensions it involves is attempted in a superficial, merely cumulative, and mechanistic way, resulting in an inadequate understanding of the real evolutionary strengths and weaknesses of the organization. Besides, the internal business environment is often analyzed separately from the external environment, ignoring and neglecting the reality in which all environments of any socioeconomic organization are always in a relationship of co-evolution and co-adjustment.

To this end, this study aims to explore whether an alternative way of evolutionary perception and analysis of the internal business environment exists. The goal is to propose a conceptual framework of "biological type" for the strategic analysis of firms, in the contexts of the Stra.Tech.Man approach (synthesis of strategy-technology-management).

\section{Methodology and Structure of the Paper}

The description of the steps that this particular analysis follows also constitutes the way of achieving the aim of perceiving the internal environment historically and evolutionarily:

1) The next section studies, under a critical perspective, the theoretical foundations of the internal business environment analysis in the strategic management literature.

2) Next, a generic exploration of the main guiding pillars for studying the internal business environment is attempted, by approaching contributions such as business resources and competitive advantages, value chain analysis, and the exploration of the "intangible nature" of the firm.

3) Then, a repositioned perception of the internal business environment is counter-proposed, based on the Stra.Tech.Man approach, which synthesizes in a "biological" and "physiological" way the spheres of strategy, technology, and management of the organization, considering them as a "cellular" basis for the structure and evolution of the internal environment for all kinds of socioeconomic organizations.

4) Finally, the last section presents the conclusions of the research and discusses its prospects. 


\section{Theoretical Roots of the Internal Business Environment Analysis}

The theoretical origin of the internal business environment analysis is detected primarily during the 1960s and 1970s, on the contributions of some pioneer business policy and strategic management theorists, who studied among other things the structure of the firm (Chandler, 1962) and business strategy (Andrews, 1971; Ansoff, 1965a).

According to Ansoff (1965b, p. 176), the successful firm must understand both its internal and external environment: "The successful firm of the future will be one which is structured so that both external and internal problems are given appropriate and continuous attention. Beyond this, the management structure will be conducive to innovation."

A fundamental finding of this analysis is that socioeconomic factors lying within the firm's boundaries are co-formulating the internal environment: "The internal environment consists of those relevant physical and social factors within the boundaries of the organization or specific decision unit that are taken directly into consideration in the decision-making behavior of individuals in that system" (Duncan, 1972, p. 314).

Based on the contributions to the internal business environment analysis, the scanning of the factors that help to realize the strengths and weaknesses of the firm was attempted, in what is called SWOT analysis. However, already for several years, the examination and finding of these strengths and weaknesses have not avoided criticisms. According to Brownlie (1989, p. 302): "Marketing writers such as Kotler et al. (1977) and Abell (1980) are noted for contributing methodologies and techniques to assist the task of internal appraisal. But for these, writing on the diagnosis of strengths and weaknesses has largely taken the form of checklists of factors to be generally rated as strengths or weaknesses."

In a similar vein, Popescu and Scarlat (2015, p. 469) argue that SWOT analysis should also take into account the interaction between the internal and external business environment dynamically and not statically, therefore not to oversimplify its findings:

"SWOT Analysis represents a very simplified view ... It provides a separate understanding of the internal strengths and weaknesses and external opportunities and threats of business organization, but it does not show us how external and internal factors are interconnected and what to do about them."

Therefore, the external environment analysis is necessary, although it is not enough to find out meticulously the internal factors influencing the firm. Claudiu, Andrei, and Gabriela (2011, p. 731) define the internal environment as follows: "The internal environment includes all elements that are endogenous to the organization, which are influenced to a great extent and totally controlled by it."

However, it seems that the usual analysis of the internal environment is limited to analyzing the strategic planning of large corporations (Becherer, Halstead, \& Haynes, 2001). It seems that it neglects the fact that the internal business environment offers the general framework where "competencies are nested and which impact their character and functioning" for all kinds of firms (Kleinschmidt, de Brentani, \& Salomo, 2010, p. 204). In this context, strategic 
planning requires a prior comprehensive understanding of the internal environment (Note 1). According to Hine and Ryan (1999), the internal environment creates in the background these circumstances allowing a firm to be (or not) more innovative. On this theoretical direction, that is, on recognizing the role of analyzing the internal environment thoroughly in terms of innovativeness, Kuratko, Hornsby, and Covin (2014, p. 39) also argue that "as research on corporate entrepreneurial activity has evolved, numerous researchers have acknowledged the importance of internal organizational dimensions to promoting and supporting an environment for innovation."

Thus, it seems that the "traditional" internal business environment analysis is critical, but also involves some shadiness:

- It seems that strategic planning that is based on a "conventional" internal environment analysis oversimplifies its diagnosis on business strengths and weaknesses by applying a rather comparative-static approach.

- Besides, even though it studies endogenous factors that lead to the firm's innovativeness, the "conventional" analysis of the business environment tends to refer only to its unfolding in large corporations, which are based on a clear organizational structure and hierarchy. This analysis can often neglect the utility it could also have in smaller firms, which are based mostly on informal structures and features.

The following section, therefore, presents the main analytical contributions that seem to deal with the internal environment from a historic and multidimensional perspective.

\section{Towards a Functional Approaching of the Internal Business Environment Elements}

An attempt to describe the internal environment concisely, as approached and implemented in the contexts of modern strategic analyses, seems essential and a prerequisite for developing an effective business strategy. Below, some of the fundamentals to understand the internal business environment analysis are presented.

\subsection{The Firm's Resources as a Significant Source of Competitive Advantages in Contemporary Strategic Analysis}

The internal business environment consists of all the resources and their synthetic forms. The resources (Grant, 1991) of a firm are all of its productive assets that are under its direct control; both tangible and intangible (Čater \& Čater, 2009). Tangible resources are the material assets of an organization, such as its production units, buildings, and financial assets. Intangible resources are non-material assets such as information, the reputation of the company, acquired knowledge, and business culture as an organic whole.

From a similar theoretical point of view, resources also are the inflows the firm draws from its economic environment: capital, labor, natural resources, and entrepreneurship. Therefore, the machinery, the working capital, and the tools also can be resources, combined with business processes, skills, and abilities of the people of the firm, their values, work ethics, and productive behavior. However, among the available resources, only a few can be called as unique resources (Costa, Cool, \& Dierickx, 2013). It is always difficult to acquire them, 
and they constitute the basis for the creation of particular competitive advantages.

According to Peters and Waterman (1982), all the productive elements of the firm constitute an evolving framework, where each sphere of the " $7 \mathrm{~s}$ " interacts with the other. In this framework, the firm internally synthesizes its structure, systems, styles of management, staff, skills, strategy, shared values, by heading towards "excellence." In practice, all of these dimensions co-exist with each other. It is impossible to change one of them, while the other spheres remain unaffected. Therefore, nothing in the business environment exists in the vacuum, and no "internal environment" exists independently of the surrounding "external environment." Of course, it is worth noting that there is an ongoing process of co-determination and co-evolution between the internal and external environment of the firm, to which the authors did not elaborate (Appendix 1).

In this "co-evolving" context between the internal and external business environment, the success or failure of the firm depend on the "comparative strengths" that the firm exercises, or the "comparative weaknesses" that cannot adequately cure. For sure, for a firm to understand its strengths and weaknesses, the final "evaluation" made by the market is critical. The higher the performance (Lechner \& Gudmundsson, 2014; Ritala, 2012) and market position for a firm is, the more likely it is for the strengths to outperform weaknesses and, therefore, for the strategy to be an appropriate one. Therefore, a firm's failure in the market may not only result from the inadequacy of the strengths or the plethora of weaknesses: the firm might not know how to capitalize on its wealth by building an effective strategy.

In any case, the comparative business strengths are the "weapons" that a firm deploys in its competitive environment. These strengths constitute the firm's competitive advantages, that is, the ability to endure, survive, and thrive in competitive conditions. Accordingly, business weaknesses are competitive disadvantages and pave the way for failure. In practice, a private firm, irrespectively of its size or age (Coad, 2018), can head towards "strategic decay" and death without sufficient strengths and many weaknesses.

Of course, all business strengths and weaknesses come from the constituents and operation of the firm's internal environment, that is, from the available resources and the specific ways it synthesizes and activates them. The resources by themselves, however, cannot create a strategic advantage. Creating a strategic advantage lies in the way the resources are employed and combined to build distinct or core competencies (Grant, 2007; Hafeez, YanBing Zhang, \& Malak, 2002; Prahalad \& Hamel, 1997); this process requires a systematic conception and valorization of the co-evolution between the internal and the external business environment.

Specifically, the firm's competence derives from the activity-process that the firm knows how to manage and realize effectively. However, not all business competencies are of the same kind and value. Core competencies are only those that the firm manages to reproduce and use in a particular way to develop its strengths. The competitors cannot easily imitate them and, therefore, firms derive out of them sustainable competitive advantages, that is, constant advantages that are difficult for the competition to replicate. Ultimately, "comparatively unique" competencies differentiate the firm strategically. Usually, a firm's core competence comes from the integration/combination of a group of specific capabilities and not fragments 
of them (Leoncini \& Montresor, 2007). This unique competence is never just a piece of the firm's assets (for example, machinery, a distribution channel, or a product). The core competence constitutes the ability to manage all of these together or some combinations of them (Appendix 2).

At least four conditions must be fulfilled to define core competencies (Maksimova, 2014):

1) Durability: signals the rate in which these resources and competencies lose value over time.

2) Duplicability: means the capability of competitors to use the same resources and competencies to imitate a firm's strength.

3) Transparency: that is, the speed in which competitors can analyze and measure a firm's comparative advantages to identify the resources and competencies providing them.

4) Transferability: refers to the capability of competitors to gather resources and competencies to imitate a firm's strategy.

However, a sole competitive advantage is not enough to ensure the firm's long-term survival and development; an advantage can be lost if a firm does not defend and cultivate it systematically and adequately (García-Morales, Jiménez-Barrionuevo, \& Mihi-Ramírez, 2011) to respond to today's rapidly changing global business environment and customer needs (Vlados, Deniozos, \& Chatzinikolaou, 2018). Moreover, this strategic dynamic depends on the extent to which it is derived from explicit knowledge (relatively easy to copy) or tacit knowledge, which are acquired through experience in the workplace (Anand, Ward, \& Tatikonda, 2010; Nonaka \& Takeuchi, 1995).

In conclusion, all the above dimensions constitute fundamental functional interpretations for the analysis of the internal business environment. It seems that the co-evolutionary perception of the internal and external environment of the firm and the exploration and finding of unique capabilities that offer a competitive advantage are analytical prerequisites for successful strategic planning and implementation. With these introductory clarifications in mind, the next section presents one more of the central concepts to approaching the internal business environment, that is, the value chain analysis.

\subsection{Value Chain Analysis}

Within every firm, a system of value-adding is always built and operates as the production process goes on, which links all work tasks and subjects, both horizontally and vertically. To achieve high performance and enhance efficiency, a firm must always produce a higher output/value compared to its production cost in every link of the process. This constant production of higher value should be happening in both the internal supplier-customer relations as well as externally (Eranda \& Abeysekera, 2015; Marca \& Zhao, 2019).

This "value chain" is, in particular, the organic set of value-creating business activities. This set is expressed as a succession of functional value-adding production links, starting from primary supplier inputs, continuing with a series of value-adding activities that relate to the 


\section{Al Macrothink}

Business and Management Horizons

ISSN 2326-0297

2019, Vol. 7, No. 2

production and marketing of a product/service, and resulting in the distribution of the final goods to the market. In this value chain, there are usually two levels of activity: primary activities, which are directly related to the production and management of the product/service, and supporting activities, which have the role of covering the needs of the primary activities.

In Porter's perspective (1985), who introduced this analytical technique, differences among competitive value chains are a vital source of competitive advantage. Different firms are characterized by different operational compositions within the productive links of their value chains, by also executing these operations with different efficiency. Some firms manage to create a considerable amount of value at a relatively low cost in some links, and some others do not. In the chain links that a firm has an advantage over its competitors, it establishes its comparative advantage over the others; accordingly, where it has a disadvantage, its competitive inefficiency takes place. Therefore, it is of utmost strategic importance for a firm to know what links are potentially useful and strategically crucial and which are falling short.

To this end, Vlados (2016) adds a third level of analysis: the synthesizing activities of the organization (Figure 1). This synthesis, which is of central importance, concerns how the three interrelated spheres of business strategy, technology, and management affect the course of the firm in the present-day global co-opetition (Gnyawali \& Park, 2011; Lacam \& Salvetat, 2017).

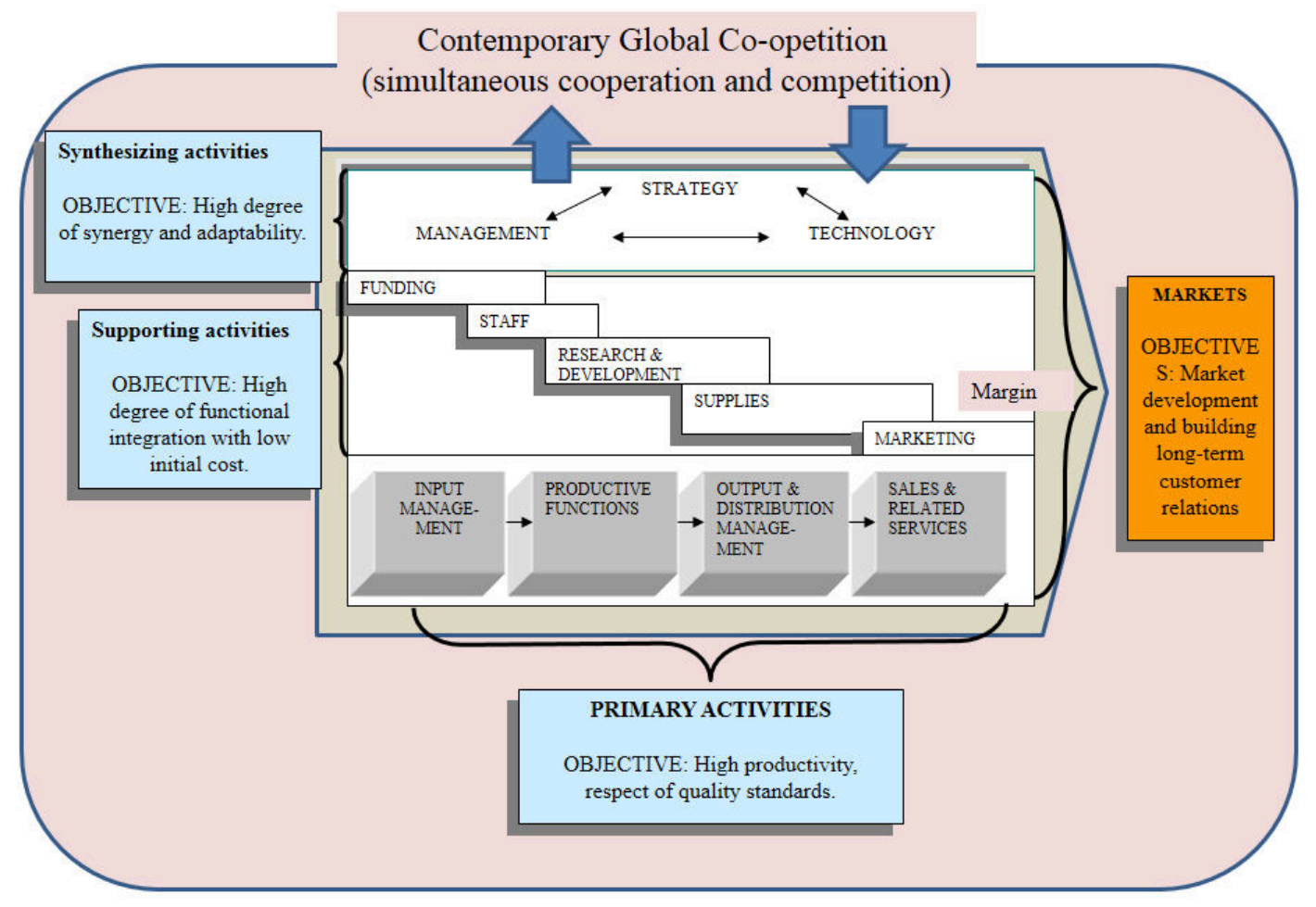

Figure 1. The firm's value chain and goals. Adapted from Vlados (2016) 
In particular, in this perspective, the general target of the primary business activities is to maintain high-quality standards throughout the chain process: from managing the inputs to the final step of selling the product to the end customer. On the supporting activities chain, at the same time, constant coordination of functional activities must be achieved, from keeping funding at competent levels, and to finding the end customer through marketing activities. The third co-evolving activities are tracked within the inner processes of business strategy, technology, and management, which, as Vlados (2004; 2016) suggests, are structurally embedded and synthesized on every socioeconomic organization, based on three dialectical questions. In particular, the strategy responds to "where is currently the organization and aims to reach, and why," technology to "how does the organization create and diffuse knowledge, and why," and the management to "how does the organization manage its resources, and why." The goal of this "augmented" value chain is how the firm can develop in the market and how to sustain long-term customer relationships.

In the value-chain approach, it is also critical to locate the strategic center of gravity of the firm, that is to say, the part of the value chain that is the most significant, where the experiences, potentials, and capabilities are concentrated (Porter, 1980). In order to spot the comparative strengths and weaknesses among the successive value-adding links, each firm should regularly perform a comparative analysis of the internal value network and understand which tasks to outsource (Gervais, 2007; Pati, Hashai, \& Zahra, 2018).

Moreover, according to Christensen (1997, p. 39): “Within a value network, each firm's competitive strategy, and particularly its past choices of markets, determines its perceptions of the economic value of a new technology. These perceptions, in turn, shape the rewards different firms expect to obtain through pursuit of sustaining and disruptive innovations." However, the author seems to place the dimension of technology outside the internal value network of the firm, instead of understanding the endogenous character of technology in every socioeconomic organization.

Despite that insufficiency, Christensen's approach emphasizes the existence of an external value network (Glückler \& Panitz, 2016). In this perspective, this sectoral and cross-sectoral value network is a hub where cross-business collaboration takes place by linking different value chains and articulating productive relationships that are necessary for the creation of a product or service. Moreover, the general context of this external to the firm value network is the global aspect; that is, the current dynamics of globalization.

Thus, the value chain analysis helps to consider how any firm should plan its internal environment strategically by taking into account all of the systemic interactions created both in the internal as well as in the external of the organization.

\subsection{Examining the "Intangible" Nature of the Firm}

No firm, irrespectively of its size, sectoral and spatial focus, "thinks" and act in a "mechanistic way": that is, a relatively simplistic perception of the management science that seems to study the behavior of the firm as a byproduct of "mechanical" procedures. As Tofler and Tofler (1998, p. viii) have argued: "Based on assumptions of linearity and equilibrium, 
and heavily quantified, the dominant management paradigm paralleled the mechanistic assumptions of western economics, which, in turn, attempted to parallel Newtonian physics. This multileveled parallelism - the belief that management 'science' fitted perfectly with economic 'science' and that both were compatible with what was known about physics made the industrial management paradigm enormously persuasive."

Despite Taylor's (1911) contribution with the first principles of scientific management, the "mechanistic" perception of the firm seems unable nowadays to answer ever more complex questions deriving from the evolutionary activity of the firm (Nelson et al., 2018). Nowadays, the firm is more of a learning organization (Argote, 2011; Jiménez-Jiménez \& Sanz-Valle, 2011), which accumulates organizational knowledge, instead of a simple machine. The firm, as an entity, accumulates knowledge through collective experience generated by the use of its systems, routines, processes, and activities. Specifically, a learning organization feedbacks learning and knowledge in its stakeholders while following a course of constant transformation and change. According to Senge (1990), learning organization means to develop specific learning capabilities, which happen on large-scale human systems that are, at the same time, technological, economic, political, and cultural, and which cannot be perceived by only focusing on one of these dimensions.

Therefore, the firm is a cultural entity that has and builds principles, values, and ideals. In particular, the business culture (Casson, 2010; Cook \& Yanow, 2011) is composed of unique values, beliefs, and traditions that are built over time through collective social effort. Business or organizational culture contains the underlying assumptions and beliefs shared by the members of an organization that define the image that the organization holds for itself and the environment. Many definitions of the concept of organizational culture exist, something indicative of the multidimensional nature of the phenomenon. For example, according to Zheng, Yang, and McLean (2010, p. 765), "organizational culture is a source of sustained competitive advantage and empirical research shows that it is a key factor to organizational effectiveness." At the same time, organizational culture bears an interdisciplinary character: "organizational culture is based on culture science in general and it is characterized by an inter-disciplinary approach; this brings methods and knowledge together, especially in sociology, psychology, economics and management" (Mohelska \& Sokolova, 2015, p. 1011). Sometimes, however, the people of the organization are incapable of perceiving its inevitable elusive nature: "organizational culture is not an easy task. In practice, it can prove to be an elusive, evolving phenomenon that is difficult for both insiders and outsiders to grasp" (Furnell, Clarke, \& Lacey, 2010, p. 6).

In one of the fundamental perspectives to the phenomenon, Schein (1985) argues that organizational culture is distinguished in three successive levels (Appendix 3):

- Artifacts: these are visible and "feelable" structures and processes or observed behavior. In general, these are difficult to decipher. Artifacts include any tangible, evident or verbally identifiable elements in an organization

- Espoused beliefs and values: these can be ideals, goals, values, aspirations, such as ideologies or rationalizations. These may or may not be congruent with behavior and 
other artifacts.

- Basic underlying assumptions: these are unconscious, taken-for-granted beliefs and values. They determine behavior, perception, thought, and feeling.

Overall, the previous dimensions are organically integrated with the overall strategic evolution of the firm ( $\mathrm{Du} \& \mathrm{Fu}, 2011$ ) and, in particular, with its strategic competencies, strategic development, and internal strategic change management (Goksoy, 2016; Rawlins, 2014). At the root of the business culture, of course, there are some of the critical components of strategy, such as core values, mission statement, vision statement, and strategic goals. The core values govern the firm and guide its strategy (Andrikopoulos, Georgakopoulos, Merika, \& Merikas, 2019; Dahlgaard-Park, 2012; Vadasi, Bekiaris, \& Andrikopoulos, 2019). The mission statement, as a direct derivative of these principles, seeks to make clear to the people of the firm and every other stakeholder the general purpose of the firm (Babnik, Breznik, Dermol, \& Šrca, 2014). The vision statement, directly linked to the firm's mission, must show what the organization aspires to become in the distant future (Kantabutra \& Avery, 2010). Therefore, any firm must express all these aspects of the business culture explicitly and systematically.

In more detail, the roles of a business vision and mission are the following (Kirkpatrick, 2017):

- They describe the future business scope.

- They specify the desired future business scale.

- They unify the strategic perspective on products, markets, and technology.

- They focus on dealing with competition.

- They set the image of the firm and the relationship with its stakeholders.

- They define the role of management and business structure.

Moreover, according to Collins and Porras (1998), firms enjoying long-term success have a core purpose and core values that remain stable, while their strategy and goals continuously adapt to an ever-changing environment. The rare ability of balance between continuity and change is closely linked to the ability to develop a vision. This perspective of the vision suggests that there are specific elements to be maintained for the future progress of the firm:

* Core ideology: it defines the permanent character of an organization. It constitutes the most significant contribution of those who created the organization and is the binding substance that maintains the cohesion of an organization over time.

- Envisioned future: it consists of an audacious goal spanning over the upcoming ten to thirty years, and a vivid description of the projected future when business goals are achieved. 
4.4 Conclusions: the Transition from the Structural Characteristics of the Firm and Business Culture to a Biological Understanding of the Firm's Internal Organizational Environment

All of the previous dimensions are of utmost importance for the survival of modern firms, irrespectively of their size and scope, within the highly pressing conditions of the current restructuring crisis of globalization (Laudicina \& Peterson, 2016; Vlados, Deniozos, Chatzinikolaou, \& Demertzis, 2018). It is critical in today's competitive conditions to find out your strategic competence, to build a genuinely innovative value chain, and to clarify your business culture. These are not just theoretical assumptions or a "luxury" for big companies only: these aspects concern all firms. However, it seems that these approaches and interpretations of the internal business environment could be enriched even further. In particular, all these fundamental contributions can fit into a "biological interpretation" of the internal environment in order to be applied in all kinds of socioeconomic organizations.

In this biological imprint, firms are "alive" rather than "mechanical" organizations (Wagner 2007; Zeleny, 1980). According to Battram (1999), there is a clear distinction between the mechanic and the biological study of organizations. A mechanical perception treats firms as factories where human resource development is carried out with regular maintenance that requires occasional oversee. In general, the mechanics of firms studies closed systems consisting of simpler subsystems whose growth (not development) is based on detailed rules. In contrast, in the biological paradigm, firms are "gardens" in which human development resembles the way we care for a "plant." Ultimately, in this sense, firms are complex systems consisting of open and adaptive systems at many different interactive levels, the development of which depends on the continuous improvement based on shared values.

\section{The Stra.Tech.Man Physiology Approach as a Counterproposal}

Moreover, to understand better the internal environment of a firm, except the above useful contributions, an evolutionary and biological perspective (Nelson \& Winter, 1982; Witt, 2006) is also particularly useful. Such a perspective that is based upon the "business biology" seems capable of dealing with the critical problem that also smaller firms are facing (Vlados \& Chatzinikolaou, 2019b). That is, how to diagnose the level of development of their internal environment and future trends. To this end, the "biological" paradigm presupposes that behind similar "quantities" may lie a vast difference in "qualities"; behind similar size, deep differentiation of different types of firms may be hidden. As Penrose (1995, p. 19) argues: "We cannot define a caterpillar and then use the same definition for a butterfly." Therefore, every firm resembles an "animal" that struggles to survive in its living environment (Kanter, 1989; Lynch \& Kordis, 1988).

According to de Geus (1997), every firm is a living organism: distinct, visible, and self-determined that, at the same time, is embedded in the larger whole. All firms, therefore, have self-consciousness and a "personality" that affect the world around them. In a similar direction, Kelly (1994) discusses the emergence of a new technological age in which human-made systems are approaching the complexity of living beings, and in which biology is the best metaphorical description for identifying ways of controlling our world. Therefore, instead of understanding the firms based on the traditional industrial model, that is, as 
production lines and self-sustained mechanical entities, in this perspective, they are parts of an ecological system of organizations.

Based on these observations of "biological type," Vlados (2004) suggests that all firms, even those with similar size, as living organisms, belong to different "physiological species"; they are different "animals." In this approach, every firm has its own "DNA," its own biological identity that contains all the "genetic information" that determines the potential of its biological development. In particular, the "biological core" of every living firm is located and determined evolutionarily within three fundamental and interconnected analytical spheres: within the strategy, technology, and management (Stra.Tech.Man synthesis). Every firm produces and reproduces its innovative evolutionary Stra.Tech.Man potential, aiming to competitive survival and development, within the evolving environment, by responding proactively to a set of three profound questions (Figure 2):

- Strategy: Where is the organization currently? Where does it heading? How will the organization reach this destination? Finally, why does it think this way?

- Technology: How does the organization draw, create, synthesize, spread, and reproduce its productive means and expertise, and why?

- Management: How does the organization manage its available resources, and why?

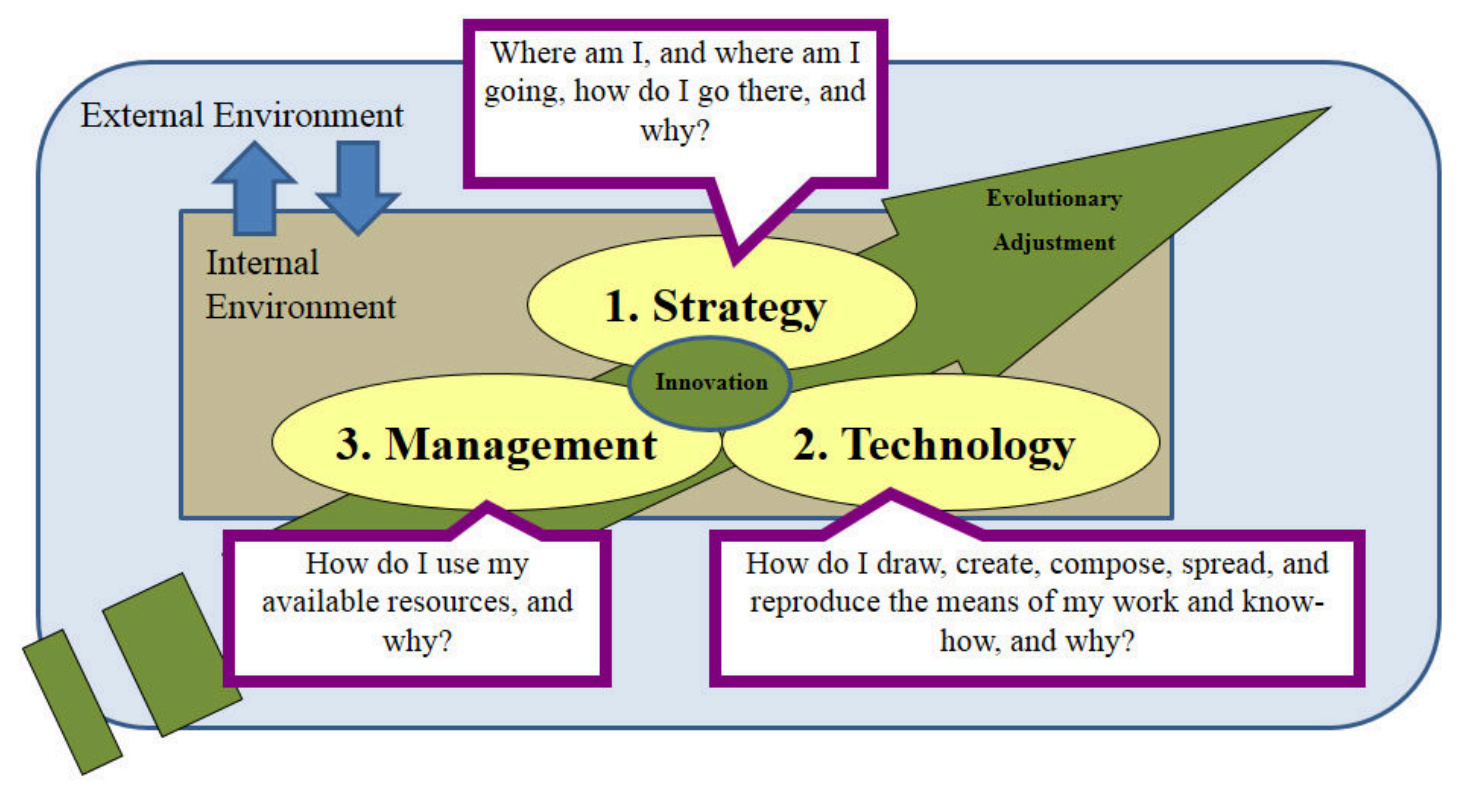

Figure 2. The Stra.Tech.Man questions refer to all socioeconomic organizations. Adapted from Vlados (2004)

Firm strategy, technology, and management - even though they are independent evolutionary spheres in analytical terms - are combined and co-determined in practice and produce innovative business potential. Firm success and innovative capacity never result from a single 


\section{I Macrothink}

Business and Management Horizons

ISSN 2326-0297

2019, Vol. 7, No. 2

sphere, but are the result of all three spheres together and the particular way their synthesis attains to give adequate answers to the changing environment. In this way, to survive and develop, every firm has to synthesize strategic, technological, and managerial dynamics, aiming to innovation that would allow the competitive advantage of the organization and sustain profitability and market efficiency. Otherwise, eventually, the firm collapses, dies, and dissolves. In this approach, the firm resembles more of a "cell" rather than a mechanic gear (McNamara, 2009).

Within the Stra.Tech.Man core, the evolutionary "physiology" of the firm is structured. A firm's physiological evolution takes place through dialectical conflicts (Vlados, Deniozos, \& Chatzinikolaou, 2019) between the Stra.Tech.Man philosophy that characterizes it, and the Stra.Tech.Man procedures that it uses. No physiological evolution of the firm, at any level, is cut off from this internal dialectical process at the Stra.Tech.Man core. Philosophy seeks to be reflected in the procedures dialectically while procedures operate in the gradual transformation of the philosophy. Neither of the two dialectical spheres (philosophy and procedures) has an evolutionary autonomy and self-sufficiency. The only way for the business philosophy to evolve, always, is the necessary prior evolution of its procedures, and vice versa. On this methodological core, the "operational axis" of the firm is built, which comprises all of the aspects of its management that often take the form of independent departments. The different administrative units, with their corresponding operational focus, are performing specific business tasks, in a back and forth relationship (Figure 3).

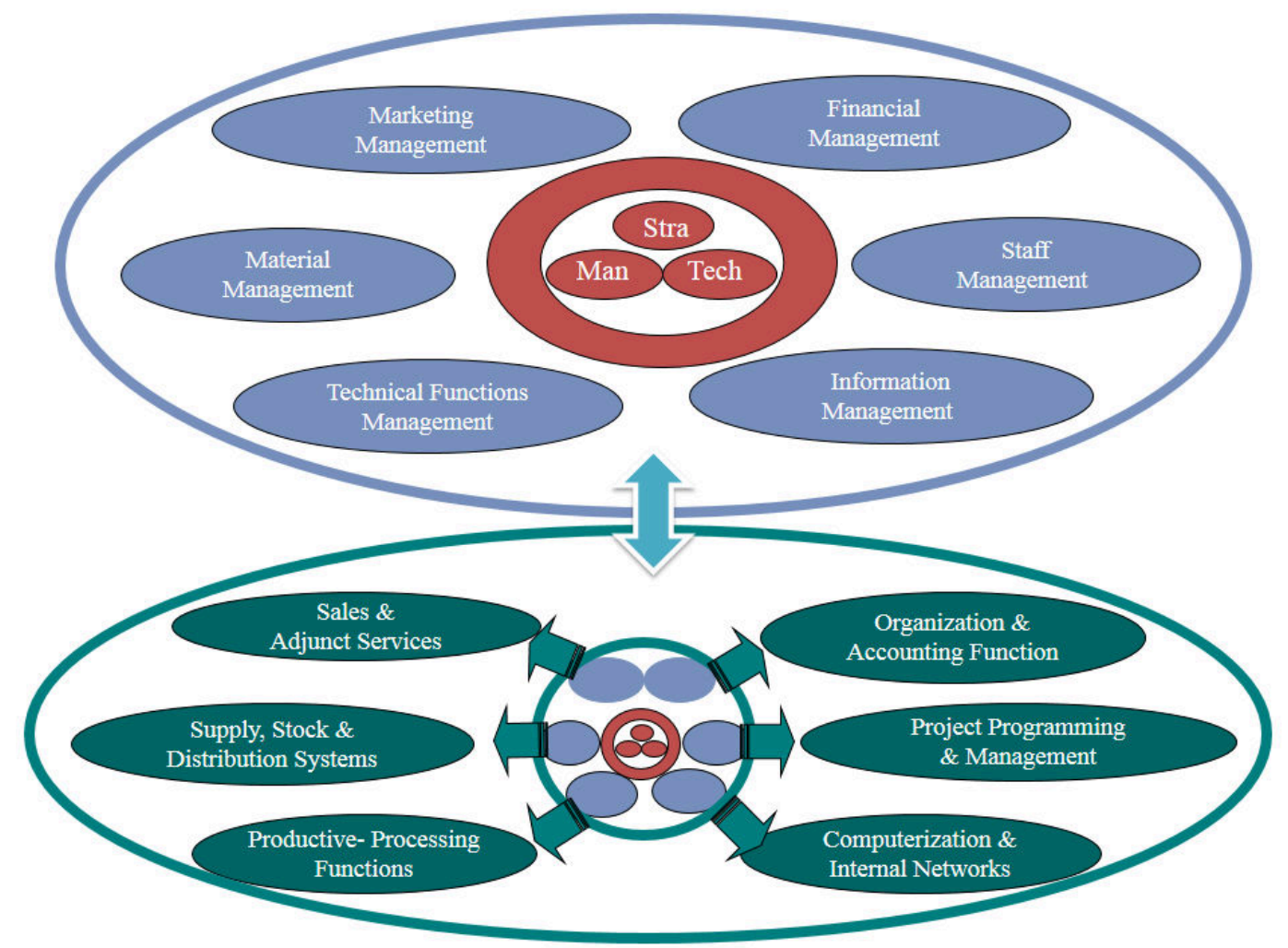

Figure 3. The cell of the firm and the various operational departments. Adapted from Vlados (2016) 
In this context, an overall mechanism to manage change seems imperative. According to Vlados (2019a), change management constitutes an analytical and practical prerequisite of innovation creation and establishment within an organizational system. Change management is the organic process that rearranges the internal environment of every organization continuously, under the light of constant external environmental changes. Specifically, "change management in Stra.Tech.Man terms" follows an evolutionary and elevating cycle of five successive steps, which build an integrated mechanism that can be utilized in the analysis of the internal business environment:

1) Creation/repositioning of strategy

2) Validating the right use of technological tools

3) Efficient management of resources

4) Innovative synthesis in Stra.Tech.Man terms

5) Assimilation of the pursued change and restart of the eternal dialectical cycle

In conclusion, in this "biological" analytical expression, all firms are "alive" and compete for survival, like "cells" within their changing and evolving socioeconomic "ecosystem." At the same time, each of them tries to utilize specific strong points and avoid specific weaknesses. Over time, the goal of every firm must be how to respond to newly emerging challenges, especially within the present context of the dynamics of globalization. In this evolutionary "game of survival," each dimension has its systemic and organic significance. A dominantly strong point today could lose its strategic importance over time. In its place, new and dominant strong points, considered secondary or marginal until yesterday, may emerge in competition. Likewise, a comparative weakness today, considered of little strategic importance, may prove critical for the firm's future survival (Vlados, 2019b; Vlados \& Chatzinikolaou, 2019c). In this perspective, all strengths and weaknesses of the "socioeconomic ecosystem" stem ultimately from the Stra.Tech.Man triangle.

Therefore, in this perspective, the Stra.Tech.Man approach constitutes a model of operational analysis of the internal evolutionary environment, capable of approaching in "living" terms all kinds of socioeconomic organizations in their evolutionary context. That is, as an approach that can give directions of strategic planning and provide an overall explanation of "organic type" to how the internal business environment is imprinted and evolves within the firm.

\section{Conclusions and Discussion}

Nowadays, the need for clear business strategies is increasingly pressing for all kinds of firms throughout the world. If you are incapable of offering something truly better from your competitors, then you are at risk of plummeting in terms of competitiveness. Thus, the cultivation of the firm's organic and evolutionary strengths and an understanding of the corresponding weaknesses are of critical importance. Naturally, this requires an adequately comparative and evolutionary analysis of the internal business environment, by the part of every firm that struggles to survive and develop. 
As this article has shown, such a perception of the internal environment has been studied by a plethora of useful and complementary analytical approaches. In conclusion, a "biological type" approach seems more capable of describing the strengths and weaknesses of all kinds, sizes, and scopes of socioeconomic organizations. The Stra.Tech.Man approach that was founded by Vlados (2004) by synthesizing interpretatively the inner spheres of strategy, technology, and management seems to be heading towards this direction.

Based on this methodological counter-proposal, which regards a "biological" understanding of the firm's structure and function, an alternative way of conceiving the firm is articulated, in evolutionary and historical terms. On this explanation, at least three critical points emerge:

- The individual parts of the internal business environment are no longer considered as autonomous but as co-evolving and co-determined analytical spheres.

- The mechanistic examination of the different dimensions of the internal environment gives its place to an organic understanding.

- The internal business environment can be understood as both a structural producer and a product of its external socioeconomic environment.

The firm as a "living organization" can give specific new answers to the pressing issue of articulating strategies in a rapidly changing external environment in the current globalization era. Understanding the internal business environment in an evolutionary and "biological" way enables us to understand that all types of organizations develop in a "physiological" way. More specifically, the analytical counter-proposal of the internal organizational environment in terms of Stra.Tech.Man (Vlados, 2019a) provides a conceptual tool for studying socio-economic organizations at their more profound structural levels of strategy, technology, and management at all levels of the organization (both at the levels of individuals and groups).

With the above, the organic and evolutionary understanding of the organizational business environment provides the necessary basis for an evolutionary SWOT analysis (Vlados, 2019b; Vlados \& Chatzinikolaou, 2019c). In the direction of an evolutionary and "correlative" SWOT analysis, the strengths and weaknesses of the socioeconomic organization are always evolutionarily comparative. There are no "absolute" opportunities or threats for all. Relative organizational weaknesses nurture specific threats while relative organizational strengths nurture specific opportunities. Based on this dynamic understanding of the organization's strengths and weaknesses, it becomes perceivable that the internal environment always interacts with the corresponding external environment. This finding can be central for today's strategic business planning since it can point to the general direction that a socioeconomic organization can follow within the quasi-chaotic transformations of the undergoing "regime" of globalization.

Of course, this methodological counterproposal of the internal business environment in evolutionary and biological terms also includes some operational limitations in today's level of analytical structure. It has not acquired yet a fully functional form, mostly in specific ways to connect with the financial performance of firms, for example, like building a new type of 
scorecard (Kaplan, 2012; Kaplan, \& Norton, 1996; Zizlavsky, 2016). Research can be made in the future in new analytical ways of enrichment (for example, action research; Coghlan \& Shani, 2017) to understand and implement this evolutionary internal business environment analysis in the business field in an integrated way.

\section{Acknowledgment}

I would like to express my gratitude to Dimos Chatzinikolaou, my Doctoral Student, who helped in the editing of this work.

\section{References}

Abell, D. F. (1980). Defining the business: The starting point of strategic planning. Englewood Cliffs, N.J.: Prentice-Hall.

Anand, G., Ward, P. T., \& Tatikonda, M. V. (2010). Role of explicit and tacit knowledge in Six Sigma projects: An empirical examination of differential project success. Journal of Operations Management, 28(4), 303-315. https://doi.org/10.1016/j.jom.2009.10.003

Andrews, K. R. (1971). The concept of corporate strategy. Homewood, Ill: Dow Jones-Irwin.

Andrikopoulos, A., Georgakopoulos, A., Merika, A., \& Merikas, A. (2019). Corporate governance in the shipping industry: Board interlocks and agency conflicts. Corporate Governance: The International Journal of Business in Society, 19(4), 613-630. https://doi.org/10.1108/CG-07-2018-0224

Ansoff, H. I. (1965a). Corporate strategy: An analytic approach to business policy for growth and expansion. New York: McGraw-Hill.

Ansoff, H. I. (1965b). The firm of the future. Harvard Business Review, 43(5), 162-178.

Argote, L. (2011). Organizational learning research: Past, present and future. Management Learning, 42(4), 439-446. https://doi.org/10.1177/1350507611408217

Babnik, K., Breznik, K., Dermol, V., \& Širca, N. T. (2014). The mission statement: Organisational culture perspective. Industrial Management \& Data Systems, 114(4), 612-627. https://doi.org/10.1108/IMDS-10-2013-0455

Battram, A. (1999). Navigating complexity: the essential guide to complexity theory in business and management. London, UK: Industrial Society.

Becherer, R. C., Halstead, D., \& Haynes, P. (2001). Marketing orientation in SMEs: Effects of the internal environment. Journal of Research in Marketing and Entrepreneurship, 3(1), 1-17. https://doi.org/10.1108/14715200180001474

Brownlie, D. T. (1989). Scanning the internal environment: Impossible precept or neglected art? Journal of Marketing Management, $4(3), \quad 300$. https://doi.org/10.1080/0267257X.1989.9964079

Casson, M. (2010). Entrepreneurship, business culture and the theory of the firm. In Z. J. Acs \& D. B. Audretsch (Eds.), Handbook of Entrepreneurship Research: An Interdisciplinary 
Survey and Introduction (pp. 249-271). New York, US: Springer New York. https://doi.org/10.1007/978-1-4419-1191-9_10

Čater, T., \& Čater, B. (2009). (In)tangible resources as antecedents of a company's competitive advantage and performance. Journal of East European Management Studies, 14(2), 186-209. https://doi.org/10.5771/0949-6181-2009-2-186

Chandler, A. D. (1962). Strategy and structure: Chapters in the history of the industrial enterprise. Cambridge: M.I.T. Press.

Christensen, C. M. (1997). The innovator's dilemma: When new technologies cause great firms to fail. Boston, MA: Harvard Business Review Press.

Claudiu, C. S., Andrei, P., \& Gabriela, P. M. (2011). Internal environment analysis techniques. Annals of the University of Oradea, Economic Science Series, 20(2), 731-736.

Coad, A. (2018). Firm age: A survey. Journal of Evolutionary Economics, 28(1), 13-43. https://doi.org/10.1007/s00191-016-0486-0

Coghlan, D., \& Shani, A. B. (2017). Inquiring in the present tense: The dynamic mechanism of action research. Journal of Change Management, 17(2), 121-137. https://doi.org/10.1080/14697017.2017.1301045

Collins, J. C., \& Porras, J. I. (1998). Built to last: Successful habits of visionary companies. London: Century Business.

Cook, S. D. N., \& Yanow, D. (2011). Culture and organizational learning. Journal of Management Inquiry, 20(4), 362-379. https://doi.org/10.1177/1056492611432809

Costa, L. A., Cool, K., \& Dierickx, I. (2013). The competitive implications of the deployment of unique resources. Strategic Management Journal, 34(4), 445-463. https://doi.org/10.1002/smj.2018

Dahlgaard-Park, S. M. (2012). Core values - the entrance to human satisfaction and commitment. Total Quality Management \& Business Excellence, 23(2), 125-140. https://doi.org/10.1080/14783363.2012.655067

Du, F., \& Fu, F. (2011). Partner selection shapes the strategic and topological evolution of cooperation. Dynamic Games and Applications, 1(3), 354. https://doi.org/10.1007/s13235-011-0015-6

Duncan, R. B. (1972). Characteristics of organizational environments and perceived environmental uncertainty. Administrative Science Quarterly, 17(3), 313-327. https://doi.org/10.2307/2392145

Eranda, N., \& Abeysekera, N. (2015). Strategic corporate social responsibility through redefining the firm's value chain. International Journal of Business and Social Research, 5(6), 23-32. https://doi.org/10.18533/ijbsr.v5i6.744

Furnell, S. M., Clarke, N., \& Lacey, D. (2010). Understanding and transforming 
organizational security culture. Information Management \& Computer Security, 18(1), 4-13. https://doi.org/10.1108/09685221011035223

García-Morales, V. J., Jiménez-Barrionuevo, M. M., \& Mihi-Ramírez, A. (2011). The influence of strategic dynamic capabilities on organizational outcomes through the organizational learning process. Industry and Innovation, 18(7), 685-708. https://doi.org/10.1080/13662716.2011.604473

Gervais, R. (2007). Global outsourcing strategies: An international reference on effective outsourcing relationships. London: Routledge. https://doi.org/10.4324/9781315254197

Geus, A. de. (1997). The living company: Growth, learning and longevity in business. London: Nicholas Brealey.

Glückler, J., \& Panitz, R. (2016). Relational upgrading in global value networks. Journal of Economic Geography, 16(6), 1161-1185. https://doi.org/10.1093/jeg/lbw033

Gnyawali, D. R., \& Park, B.-J. (Robert). (2011). Co-opetition between giants: Collaboration with competitors for technological innovation. Research Policy, 40(5), 650-663. https://doi.org/10.1016/j.respol.2011.01.009

Goksoy, A. (2016). Organizational change management strategies in modern business. IGI Global. https://doi.org/10.4018/978-1-4666-9533-7

Grant, R. (2007). Contemporary strategy analysis. London: Blackwell.

Grant, R. M. (1991). The resource-based theory of competitive advantage: Implications for strategy formulation. California Management Review, 33(3), 114-135. https://doi.org/10.2307/41166664

Hafeez, K., YanBing Zhang, \& Malak, N. (2002). Core competence for sustainable competitive advantage: A structured methodology for identifying core competence. IEEE Transactions on Engineering Management, 49(1), 28-35. https://doi.org/10.1109/17.985745

Hine, D., \& Ryan, N. (1999). Small service firms - creating value through innovation. Managing Service Quality: An International Journal, 9(6), 411-422. https://doi.org/10.1108/09604529910302109

Jiménez-Jiménez, D., \& Sanz-Valle, R. (2011). Innovation, organizational learning, and performance. Journal of Business Research, 64(4), 408-417. https://doi.org/10.1016/j.jbusres.2010.09.010

Kantabutra, S., \& Avery, G. C. (2010). The power of vision: Statements that resonate. Journal of Business Strategy, 31(1), 37-45. https://doi.org/10.1108/02756661011012769

Kanter, R. M. (1989). When giants learn to dance: Mastering the challenges of strategy, management, and careers in the 1990s. London: Unwin.

Kaplan, R. S. (2012). The balanced scorecard: Comments on balanced scorecard commentaries. Journal of Accounting \& Organizational Change, 8(4), 539-545. 
https://doi.org/10.1108/18325911211273527

Kaplan, R. S., \& Norton, D. P. (1996). The balanced scorecard: Translating strategy into action. Boston: Harvard Business Review Press.

Kelly, K. (1994). Out of control: The new biology of machines, social systems and the economic world. New York: Basic Books.

Kirkpatrick, S. A. (2017). Understanding the role of vision, mission, and values in the hpt model. Performance Improvement, 56(3), 6-14. https://doi.org/10.1002/pfi.21689

Kleinschmidt, E., de Brentani, U., \& Salomo, S. (2010). Information processing and firm-internal environment contingencies: Performance impact on global new product development. Creativity \& Innovation Management, 19(3), 200. https://doi.org/10.1111/j.1467-8691.2010.00568.x

Kotler, P., Gregor, W., \& Rogers, W. (1977). The marketing audit comes of age. Sloan Management Review; Cambridge, 18(2), 25-44.

Kuratko, D. F., Hornsby, J. S., \& Covin, J. G. (2014). Diagnosing a firm's internal environment for corporate entrepreneurship. Business Horizons, 57(1), 37-47. https://doi.org/10.1016/j.bushor.2013.08.009

Lacam, J. S., \& Salvetat, D. (2017). The complexity of co-opetitive networks. Business Process Management Journal, 23(1), 176-195. https://doi.org/10.1108/BPMJ-12-2015-0187

Laudicina, P. A., \& Peterson, E. R. (2016). From Globalization to Islandization. Retrieved from ATKearney website: https:/www.atkearney.com/web/global-business-policy-council/article?/a/from-globalizationto-islandization

Lechner, C., \& Gudmundsson, S. V. (2014). Entrepreneurial orientation, firm strategy and small firm performance. International Small Business Journal, 32(1), 36-60. https://doi.org/10.1177/0266242612455034

Leoncini, R., \& Montresor, S. (Eds.). (2007). Dynamic capabilities between firm organisation and local systems of production. London: Routledge. https://doi.org/10.4324/9780203937396

Lynch, D., \& Kordis, P. L. (1988). Strategy of the dolphin: Winning elegantly by coping powerfully in a world turbulent with change. Ft. Collins, Colo.: Brain Technologies Corp.

Maksimova, V. (2014). Conditions for sustainability of the organization's competitive advantage. Izvestiya - Journal of University of Economics, (4), 38-51.

Marca, N. J. F., \& Zhao, Y.-Y. (2019). Customizing the knowledge flow across a firm's internal value chain. Journal of Marketing Development and Competitiveness, 13(1), 116-132. https://doi.org/10.33423/jmdc.v13i1.686

McNamara, D. E. (2009). From Fayol's mechanistic to today's organic functions of management. American Journal of Business Education, 2(1), 63-78. 
https://doi.org/10.19030/ajbe.v2i1.4023

Mohelska, H., \& Sokolova, M. (2015). Organisational culture and leadership - Joint vessels? Procedia - Social and Behavioral Sciences, 171, 1011-1016. https://doi.org/10.1016/j.sbspro.2015.01.223

Nelson, R., Dosi, G., Helfat, C., Winter, S., Pyka, A., Saviotti, P., ... Dopfer, K. (2018). Modern Evolutionary Economics: An Overview. Cambridge: Cambridge University Press. https://doi.org/10.1017/9781108661928

Nelson, R., \& Winter, S. (1982). An evolutionary theory of economic change. Cambridge, MA; London, UK: The Belknap Press of Harvard University Press.

Nonaka, I., \& Takeuchi, H. (1995). The knowledge-creating company: How Japanese companies create the dynamics of innovation. New York: Oxford University Press. https://doi.org/10.1016/0024-6301(96)81509-3

Pati, R. K., Hashai, N., \& Zahra, S. A. (2018). Outsourcing and firm performance: The moderating effect of business group characteristics. Academy of Management Proceedings, 2018(1), 12790. https://doi.org/10.5465/AMBPP.2018.12790abstract

Penrose, E. (1995). The theory of the growth of the firm (First published in 1959). Oxford, New York: Oxford University Press. https://doi.org/10.1093/0198289774.001.0001

Peters, T. J., \& Waterman, R. H. (1982). In search of excellence: Lessons from America's best-run companies. New York: Harper \& Row.

Popescu, F., \& Scarlat, C. (2015). Limits of SWOT analysis and their impact on decisions in early warning systems. SEA: Practical Application of Science, 3(1), 467-472.

Porter, M. (1980). Competitive strategy: Techniques for analyzing industries and competitors. New York: Free Press.

Porter, M. (1985). Competitive advantage: Creating and sustaining superior performance. New York: Free Press.

Prahalad, C. K., \& Hamel, G. (1997). The core competence of the corporation. In D. Hahn \& B. Taylor (Eds.), Strategische Unternehmungsplanung / Strategische Unternehmungsführung: Stand und Entwicklungstendenzen (pp. 969-987). Heidelberg: Physica-Verlag HD. https://doi.org/10.1007/978-3-662-41482-8_46

Rawlins, J. D. (2014). Mythologizing change: Examining rhetorical myth as a strategic change management discourse. Business and Professional Communication Quarterly, 77(4), 453-472. https://doi.org/10.1177/2329490614543136

Ritala, P. (2012). Coopetition strategy - when is it successful? Empirical evidence on innovation and market performance. British Journal of Management, 23(3), 307-324. https://doi.org/10.1111/j.1467-8551.2011.00741.x

Schein, E. H. (1985). Organizational culture and leadership. San Francisco: Jossey-Bass. 
Senge, P. M. (1990). The fifth discipline: The art and practice of the learning organization. New York: Doubleday/Currency.

Taylor, F. W. (1911). The principles of scientific management. New York; London: Harper.

Tofler, A., \& Tofler, H. (1998). Foreword by Alvin and Heidi Toffler. In R. Gibson (Ed.), Rethinking the future: Rethinking business principles, competition, control \& complexity, leadership, markets and the world (pp. viii-x). London: Nicholas Brealey.

Vadasi, C., Bekiaris, M., \& Andrikopoulos, A. (2019). Corporate governance and internal audit: An institutional theory perspective. Corporate Governance: The International Journal of Business in Society (ahead-of-print). https://doi.org/10.1108/CG-07-2019-0215

Vlados, Ch. (2004). La dynamique du triangle stratégie, technologie et management: L'insertion des entreprises grecques dans la globalisation (Thèse de doctorat de Sciences Économiques, Université de Paris X-Nanterre). Retrieved from http://www.theses.fr/2004PA100022

Vlados, Ch. (2016). Strategy of small and medium sized enterprises, in conditions of crisis: The Stra.Tech.Man approach. Athens: Kritiki Publications. [Book published in Greek under

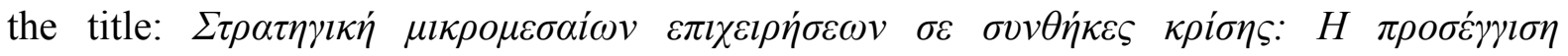
STRA.TECH.MAN]

Vlados, Ch. (2019a). Change management and innovation in the "living organization": The Stra.Tech.Man approach. Management Dynamics in the Knowledge Economy, 7(2), 229-256.

Vlados, Ch. (2019b). On a correlative and evolutionary SWOT analysis. Journal of Strategy and Management, 12(3), 347-363. https://doi.org/10.1108/JSMA-02-2019-0026

Vlados, Ch., \& Chatzinikolaou, D. (2019a). Methodological redirections for an evolutionary approach of the external business environment. Journal of Management and Sustainability, 9(2), 25-46. https://doi.org/10.5539/jms.v9n2p25

Vlados, Ch., \& Chatzinikolaou, D. (2019b). Strategy perception and implementation on less developed business ecosystems micro and small enterprises: The service sector of Eastern Macedonia and Thrace. Business Management and Strategy, 10(2), 27-63. https://doi.org/10.5296/bms.v10i2.15008

Vlados, Ch., \& Chatzinikolaou, D. (2019c). Towards a restructuration of the conventional SWOT analysis. Business and Management Studies, 5(2), 76-84. https://doi.org/10.11114/bms.v5i2.4233

Vlados, Ch., Deniozos, N., \& Chatzinikolaou, D. (2018). Global crisis, innovation and change management: Towards a new systemic perception of the current globalization restructuring. International Business Research, 11(8), 9-29. https://doi.org/10.5539/ibr.v11n8p9

Vlados, Ch., Deniozos, N., \& Chatzinikolaou, D. (2019). Dialectical prerequisites on geopolitics and geo-economics in globalization's restructuration era. Journal of Economic 
and Social Thought, 6(2), 65-92. https://doi.org/10.1453/jest.v6i2.1877

Vlados, Ch., Deniozos, N., Chatzinikolaou, D., \& Demertzis, M. (2018). Towards an evolutionary understanding of the current global socio-economic crisis and restructuring: From a conjunctural to a structural and evolutionary perspective. Research in World Economy, 9(1), 15-33. https://doi.org/10.5430/rwe.v9n1p15

Wagner, A. (2007). Robustness and evolvability in living systems. Princeton, NJ: Princeton University Press.

Witt, U. (2006). Evolutionary concepts in economics and biology. Journal of Evolutionary Economics, 16(5), 473-476. https://doi.org/10.1007/s00191-006-0034-4

Zeleny, M. (1980). Autopoiesis, a theory of living organizations. New York, NY: Elsevier Science Ltd.

Zheng, W., Yang, B., \& McLean, G. N. (2010). Linking organizational culture, structure, strategy, and organizational effectiveness: Mediating role of knowledge management. Journal of Business Research, 63(7), 763-771. https://doi.org/10.1016/j.jbusres.2009.06.005

Zizlavsky, O. (2016). Innovation scorecard: Conceptual framework of innovation management control system. Journal of Global Business \& Technology, 12(2), 10-27.

\section{Note}

Note 1. On a more thorough explanation and evolutionary conception of the external environment, the work of Vlados and Chatzinikolaou (2019a) is useful.

\section{Appendix}

Appendix 1. The 7s framework. This figure is adapted from Peters and Waterman (1982), who argue that the productive elements of the internal organizational environment derive from the firm's shared values, structure, systems, style, staff, skills, and strategy. This analysis of the internal organizational environment involves necessarily an external environment analysis as well, a fact that the authors do not seem to emphasize. 


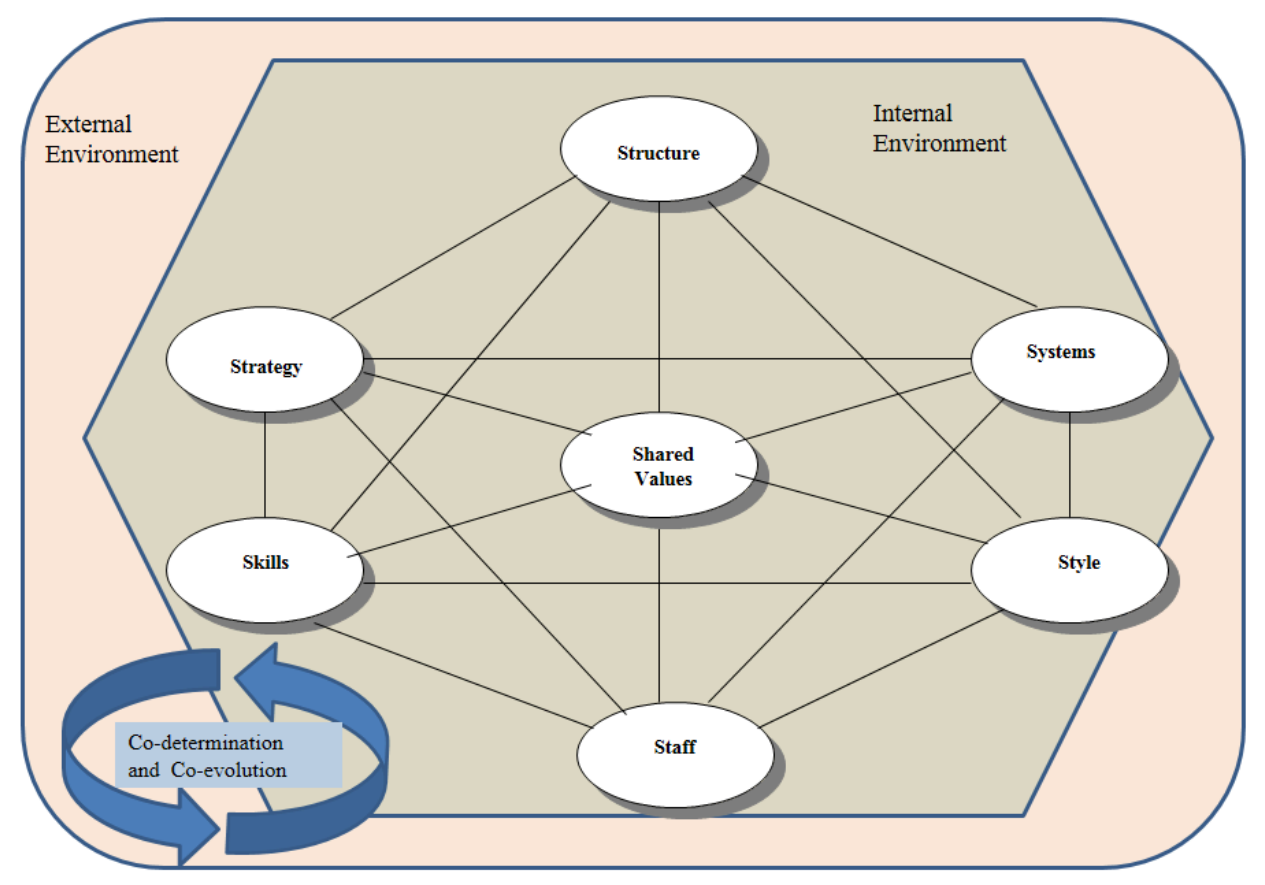

Appendix 2. Central components of internal analysis to create a sustainable competitive advantage. This figure is adapted from Vlados (2016), who argues that the internal organizational environment analysis must escalate to provide a sustainable competitive advantage. It has to start from the firm's resources, which constitute the source for capabilities, which can transform in turn in core competencies to end up with a sustainable competitive advantage. Throughout the whole process, a continuous dialectical co-evolution exists between the internal and external organizational environment. 


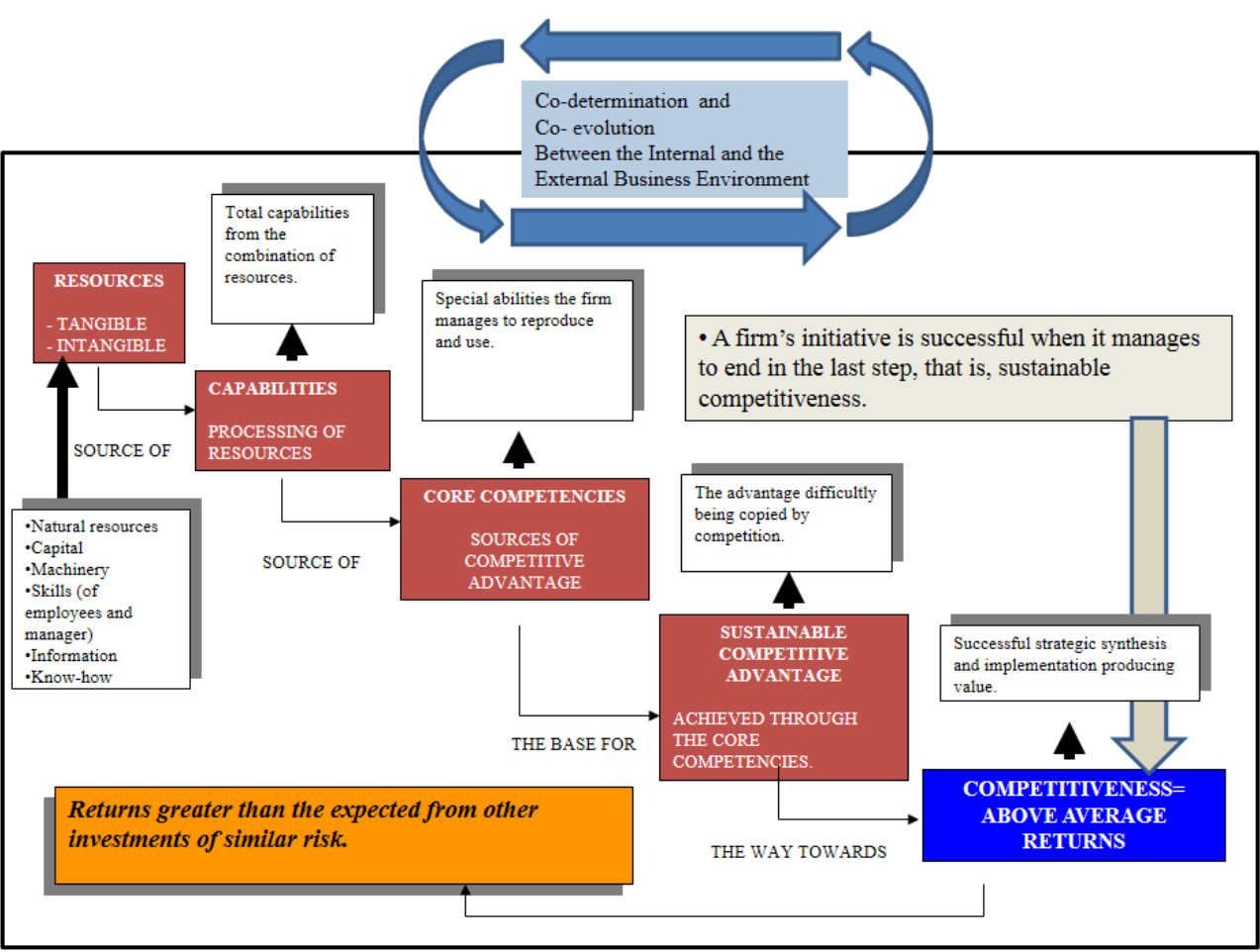

Appendix 3. This figure is based on Edgar Schein's (1985) three levels of organizational culture. Business culture constitutes an aspect of the internal environment that interacts, of course, dynamically with the external environment.

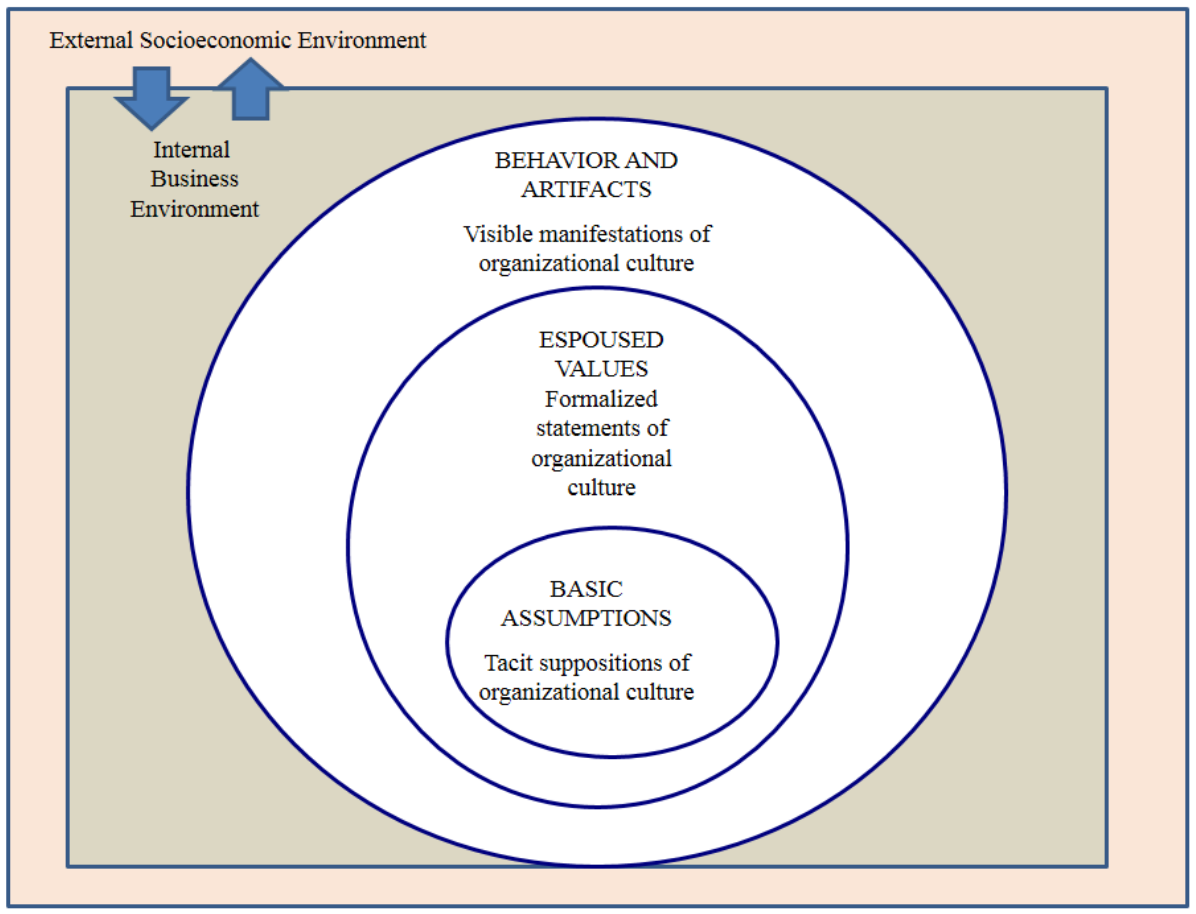




\section{Macrothink}

\section{Copyright Disclaimer}

Copyright for this article is retained by the author(s), with first publication rights granted to the journal.

This is an open-access article distributed under the terms and conditions of the Creative Commons Attribution license (http://creativecommons.org/licenses/by/4.0/). 